\title{
Inflammation-related gene polymorphisms associated with Parkinson's disease: an updated meta-analysis
}

\author{
Zulvikar Syambani Ulhaq ${ }^{1 *}$ and Cristian Peinado Garcia ${ }^{2}$
}

\begin{abstract}
Background: Strong evidence supports the involvement of inflammation processes in the development and progression of Parkinson's disease (PD), where increasingly correlations have been identified between genetic variations in inflammation-related genes and PD. However, data varies between studies. Therefore, we conducted a meta-analysis to clarify associations between inflammation-related gene polymorphisms and PD risk.

Methods: All studies were identified through online databases. Pooled and stratified groups based on racial descent were assembled to evaluate associations between polymorphisms and PD.

Results: The pooled results showed that protective effects for PD were observed for (1) IL-1a -889 C/T in Asian populations ( $T$ vs. $C, \mathrm{OR}=0.831, P=0.031 ; \pi+\mathrm{CT}$ vs. CC, $\mathrm{OR}=0.827, P=0.049$ ); (2) IL-6 -176 G/C in Caucasian populations (CC + GC vs. GG, OR=0.656, $P=0.000$; $G C$ vs. GG, $\mathrm{OR}=0.673, P=0.000$ ); (3) IL-8 $-251 \mathrm{~A} / \mathrm{T}$ (T vs. A, $\mathrm{OR}=0.812, P=0.041 ; \pi$ vs. $\mathrm{AT}+\mathrm{AA}, \mathrm{OR}=0.663, P=0.012$ ), particularly in Caucasian populations (TT vs. AT + $\mathrm{AA}, \mathrm{OR}=0.639, P=0.010) ;(4) \mathrm{IL}-10-819 \mathrm{~T} / \mathrm{C}$ (C vs. T, $\mathrm{OR}=0.742$, $P=0.034) ;(5) \mathrm{IL}-18-607 \mathrm{C} / \mathrm{A}$ (AA + CA vs. CC, $\mathrm{OR}=0.597, P=0.015 ; \mathrm{CA}$ vs. $C \mathrm{C}, \mathrm{OR}=0.534, P=0.005$ ), and (6) $\mathrm{CCR} 2+190 \mathrm{G} / \mathrm{A}$ (AA vs. $\mathrm{GA}+\mathrm{GG}, \mathrm{OR}=0.552, P=0.018$; AA vs. GG; $\mathrm{OR}=0.554 ; 95 \% \mathrm{Cl} 0.336-0.914, P=0.005)$. An increased risk of PD was associated with IL-10 - $1082 \mathrm{G} / \mathrm{A}$ in Asian populations ( $A$ vs. $\mathrm{G}, \mathrm{OR}=1.731, P=0.000 ; \mathrm{AA}+\mathrm{GA}$ vs. $\mathrm{GG}, \mathrm{OR}=1.910, P=0.000$ ). No significant associations with PD were observed for polymorphisms in IL-1 $\beta-511$ C/T, IL-10 -592 C/A, IL-18-137 G/C, TNFa -863 C/A, TNFa -857 C/T, TNFa -308 G/A, IFNY +874 T/A, and MCP1/CCL2 +2518 A/G.
\end{abstract}

Conclusions: We suggest that IL-1a -889, IL-6 -176, IL-8 -251, IL-10 -1082, IL-10 -819, IL-18 -607, and CCR2 +190 polymorphisms may be associated with PD risk; however, further studies must verify these conclusions.

Keywords: Inflammation, Cytokines, Chemokines, Polymorphism, Parkinson's disease

\section{Background}

Parkinson's disease (PD) is a neurodegenerative disorder characterized by the slow and progressive degeneration of dopaminergic (DA) neurons in the substantia nigra [1-4]. DA is a neurotransmitter synthesized by tyrosine hydroxylase $(\mathrm{TH})$, which functions in movement control [5]. Thus, the primary motor symptoms of PD include

\footnotetext{
* Correspondence: zulhaq@kedokteran.uin-malang.ac.id

'Department of Biomedical Science, Faculty of Medicine and Health Sciences, Maulana Malik Ibrahim Islamic State University of Malang, Batu, East Java 65151, Indonesia

Full list of author information is available at the end of the article
}

bradykinesia, rest tremors, rigidity, and postural instability [6-9]. Although PD pathogenesis appears to be multifactorial in nature, growing evidence strongly suggests that a chronic inflammatory mechanistic process is associated with DA neuronal death [10-13]. Indeed, elevated levels of pro-inflammatory mediators such as TNFo, IL-1 $\beta$, IL-3, IL-2, and IL- 6 have been detected in the substantia nigra, striatum, and cerebrospinal fluid (CSF) of PD patients $[6,11,12,14-16]$.

DA neuron degeneration has been linked with microglial cell activation $[4,7,17]$, leading to the promotion of inflammatory processes in PD. Microglia are resident immune

\section{Springer Open}

( ) The Author(s). 2020 Open Access This article is licensed under a Creative Commons Attribution 4.0 International License, which permits use, sharing, adaptation, distribution and reproduction in any medium or format, as long as you give appropriate credit to the original author(s) and the source, provide a link to the Creative Commons licence, and indicate if changes were made. The images or other third party material in this article are included in the article's Creative Commons licence, unless indicated otherwise in a credit line to the material. If material is not included in the article's Creative Commons licence and your intended use is not permitted by statutory regulation or exceeds the permitted use, you will need to obtain permission directly from the copyright holder. To view a copy of this licence, visit http://creativecommons.org/licenses/by/4.0/. 
Inflammation-related gene polymorphisms and PD

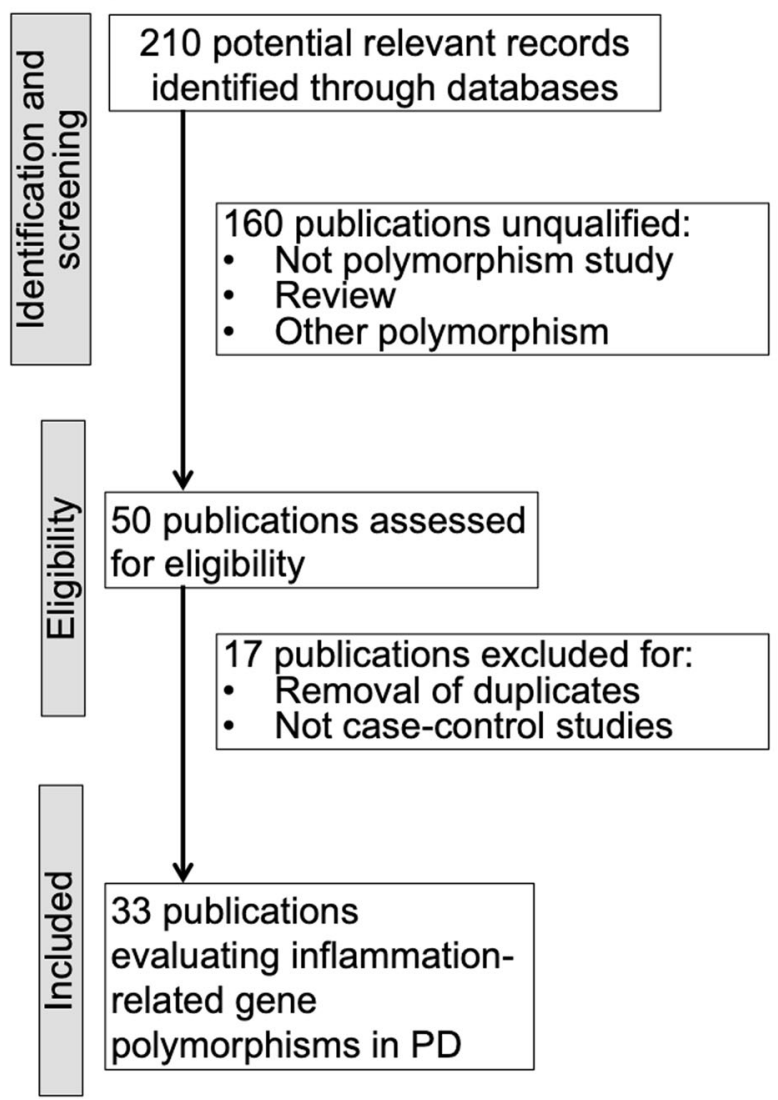

Fig. 1 The study selection process

cells in the central nervous system (CNS) that play important roles in a majority of brain disorders. Leukocyte infiltration promoted by degenerated neurons also stimulates microglia activation [18] and is modulated by chemokines. Among these molecules, MCP-1 (monocyte chemoattractant protein-1; CCL2), IL-8 (C-X-C Motif Chemokine Ligand $8, \mathrm{CXCL} 8$ ), and its receptor CCR2/5 (C-C chemokine receptor type 2/5) are reported to be involved in $\mathrm{PD}$ etiology [19-21].

It is believed that genetic variations (polymorphisms) in cytokines and chemokines as well as their corresponding receptors are associated with the mechanism of PD. To date, it is unclear whether these polymorphisms correlate with PD development and progression, as several studies are equivocal in this regard. Previous meta-analyses have been investigated associations between inflammation and PD risk $[1,22,23]$; however, these studies focused on cytokine polymorphisms, rather than chemokines and their receptors. Therefore, we provide an updated comprehensive meta-analysis, summarizing the latest studies evaluating associations between inflammation-related gene polymorphisms and PD.

\section{Methods}

Literature search

A literature search was conducted using PubMed, Google Scholar, Scopus, and Web of Science. Keywords including "cytokine," "chemokine," "inflammatory," "tumor necrosis factor (TNF)," and "Parkinson's disease (PD)" were used singularly and in combination. The literature search was conducted up to the September 30 2019. Inclusion criteria were (1) studies evaluating associations between inflammation-related gene polymorphisms and PD risk, and (2) case-control designed studies.

\section{Data extraction}

The following data were extracted: (1) name of the first author, (2) year of publication, (3) country of origin, (4) number of cases and controls, and (5) number of genotypes in cases and controls.

\section{Statistical analyses}

Meta-analyses for each gene polymorphism were performed for two or more studies. The genotype frequency of the inflammation-related gene polymorphism was tested for deviation from Hardy-Weinberg equilibrium 
(HWE), against control subjects. Genetic associations were assessed using different genetic models, including allelic (mutant type (M) vs. wild type (W)), recessive (MM vs. WM + WW), dominant (MM + WM vs. WW), homozygous (MM vs. WW), and heterozygous (WM vs. $\mathrm{WW}$ ). Associations between inflammation-related gene polymorphisms and $\mathrm{PD}$ risk were calculated by the pooled odds ratio (OR) and 95\% confidence intervals (CI). $Z$ tests were used to evaluate the significance of the pooled effect size.

Heterogeneity among studies was evaluated using the $Q$ test and $I^{2}$ statistic [24]. A significant $Q$ test $(P<0.10)$ indicated heterogeneity across studies. The $I^{2}$ statistic indicated no (0-24.9\%), low (25-49.9\%), moderate (50$74.9 \%)$, or high $(75-100 \%)$ study heterogeneity. The random-effect model (REM) was used if heterogeneity existed; otherwise, the fixed-effect model (FEM) was used. Subgroup analysis was stratified by the racial descent of subjects. Begg's funnel plots and Egger's regression tests were performed to assess potential publication bias [25]. A sensitivity analysis was conducted if two or more studies were included in a meta-analysis. However, the associations did not change (data not shown). A $P<$ 0.05 value indicated statistical significance.

\section{Results}

Thirty-three studies were retrieved (Supplemental Table 1). The study selection process is described (Fig. 1). Ten studies evaluated PD associations with IL- $1 \alpha-889 \mathrm{C} / \mathrm{T}$ (rs1800587) [6, 8, 13, 15, 26-31]. Only two out of the ten studies $[15,27]$ did not comply with the HWE $(P<0.05)$ (Supplemental Table 1). No associations were found for all genetic models, which is in line with previous reports $[1,22]$. After excluding the non-compliant HWE studies, the associations remain unchanged (Supplemental Table 2 ). However, the results showed that significant associations were observed for allelic ( $\mathrm{T}$ vs. $\mathrm{C}, \mathrm{OR}=0.831 ; 95 \%$ CI $0.702-0.983, P=0.031, I^{2}=0 \%$, Fig. 2a) and dominant $(\mathrm{TT}+\mathrm{CT}$ vs. $\mathrm{CC}, \mathrm{OR}=0.827 ; 95 \%$ CI 0.684-0.999, $P=$ 0.049; $I^{2}=0 \%$, Fig. 2b) models in Asian populations. For assessment of the IL-1 $\beta-511 \mathrm{C} / \mathrm{T}$ (rs16944) polymorphism, all eligible studies were included (Supplemental Table 1) [2, 8, 11, 15, 26, 28, 30-32], which differed slightly from a previous study [22]. Similarly,

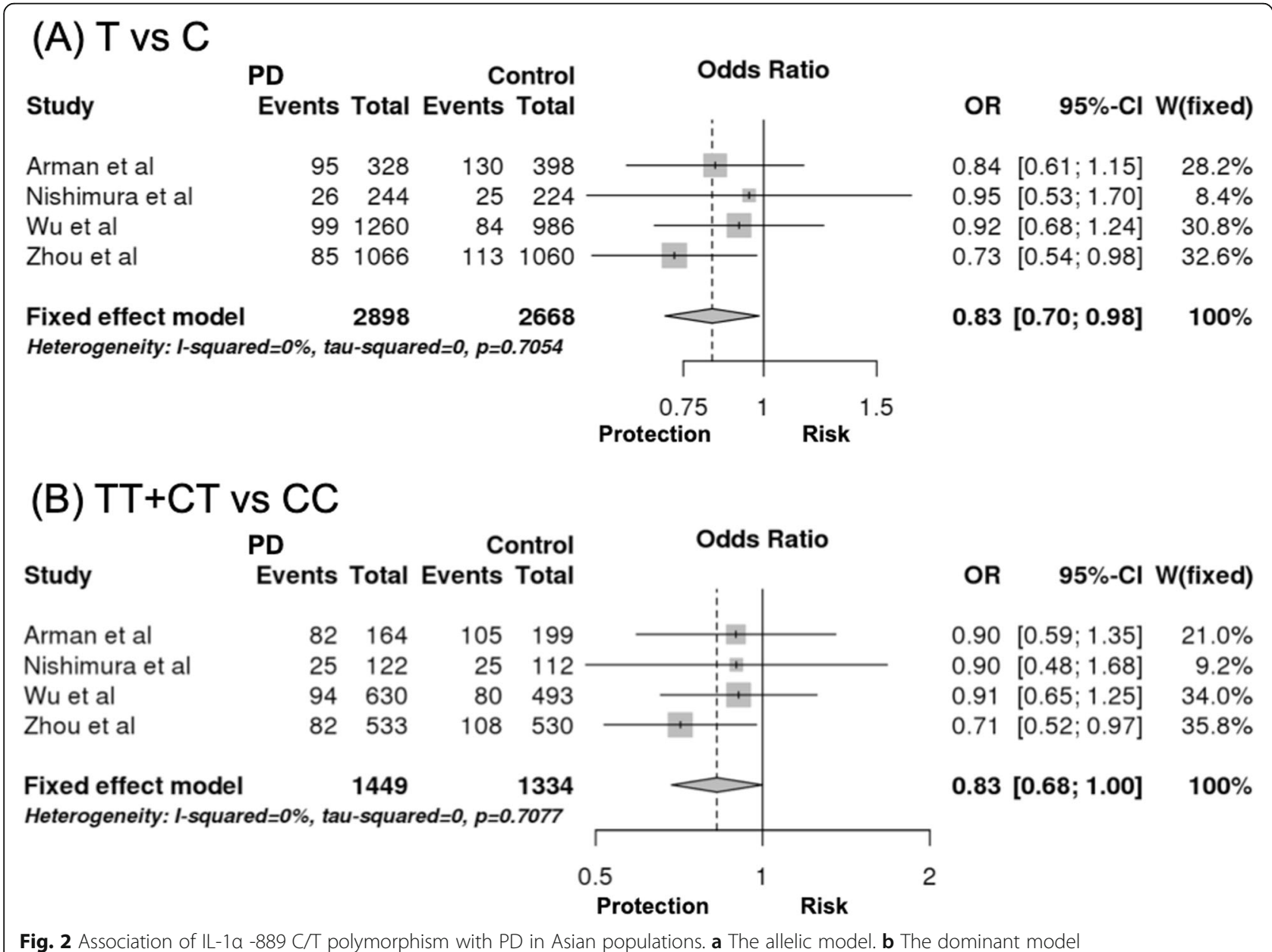


no associations were observed, neither in Caucasian nor Asian populations (Supplemental Table 2).

Previously, the C allele of IL-6 -176 G/C (rs1800795) showed protective effects for PD in Caucasian populations $[13,14,17]$. In this meta-analysis, two additional studies [7, 33] were also included. Significant associations were found for the dominant $(\mathrm{CC}+\mathrm{GC}$ vs. GG, $\mathrm{OR}=0.656$; $95 \%$ CI $0.545-0.790, P=0.000, I^{2}=48.33 \%$, Fig. 3a) and heterozygous (GC vs. GG, OR $=0.673 ; 95 \%$ CI $0.553-0.818, P=0.000, I^{2}=0 \%$, Fig. 3b) models of IL-6 -176 G/C clusters in four Caucasian population studies. Hence, these results strengthen the fact that the $\mathrm{C}$ allele in the IL-6 -176 G/C polymorphism was associated with a lower risk of PD, particularly in Caucasian populations.

While previous studies have analyzed associations between the IL-10-1082 G/A (rs1800896) polymorphism with PD [2, 12, 13, 17, 34], none have been established with IL-10 -819 T/C (rs1800871) and IL-10 -592 C/A (rs1800872) polymorphisms [4, 12, 34, 35]. In this metaanalysis, three additional studies $[33,36,37]$ were included for the analysis of IL-10 -1082 G/A polymorphisms. Our analyses showed that the A allele (A vs. G, OR = 1.731; 95\% CI 1.338-2.239, $P=0.000, I^{2}=0 \%$, Fig. 4a), and the dominant model (AA + GA vs. GG, OR = 1.910; 95\% CI 1.106-3.297, $P=0.000, I^{2}=65.20 \%$, Fig. 4b) from Asian populations were associated with PD risk. This observation was in contrast with a previous report indicating a lack of association between the IL-10 -1082 G/A polymorphism and PD [22]. Moreover, it showed that the $\mathrm{C}$ allele of IL-10 $-819 \mathrm{~T} / \mathrm{C}$ had a lower risk of developing PD $\left(\mathrm{C}\right.$ vs. T, OR $=0.742 ; 95 \%$ CI $0.628-0.878, P=0.034, I^{2}=$ $58.30 \%$, Fig. 4c), though this does not apply for IL-10-592 C/A (Supplemental Table 2).

The role of TNF $\alpha-1031 \mathrm{~T} / \mathrm{C}$ and $-308 \mathrm{G} / \mathrm{A}$ (rs1800629) in PD was previously evaluated [22, 23]. Here, we evaluated two additional TNF $\alpha$ polymorphisms; (TNF $\alpha-863 \mathrm{C} / \mathrm{A}$ and TNF $\alpha-857 \mathrm{C} / \mathrm{T})$ [ $[8,38]$. In total, eight studies were used for the TNF $\alpha-308 \mathrm{G} / \mathrm{A}$ meta-analysis $[2,8,9,11,14,16,33,34]$. One study relating to TNF $\alpha-308$ G/A [34] did not comply with HWE (Supplemental Table 1); however, when excluded,

\section{(A) $C C+G C$ vs $G G$}

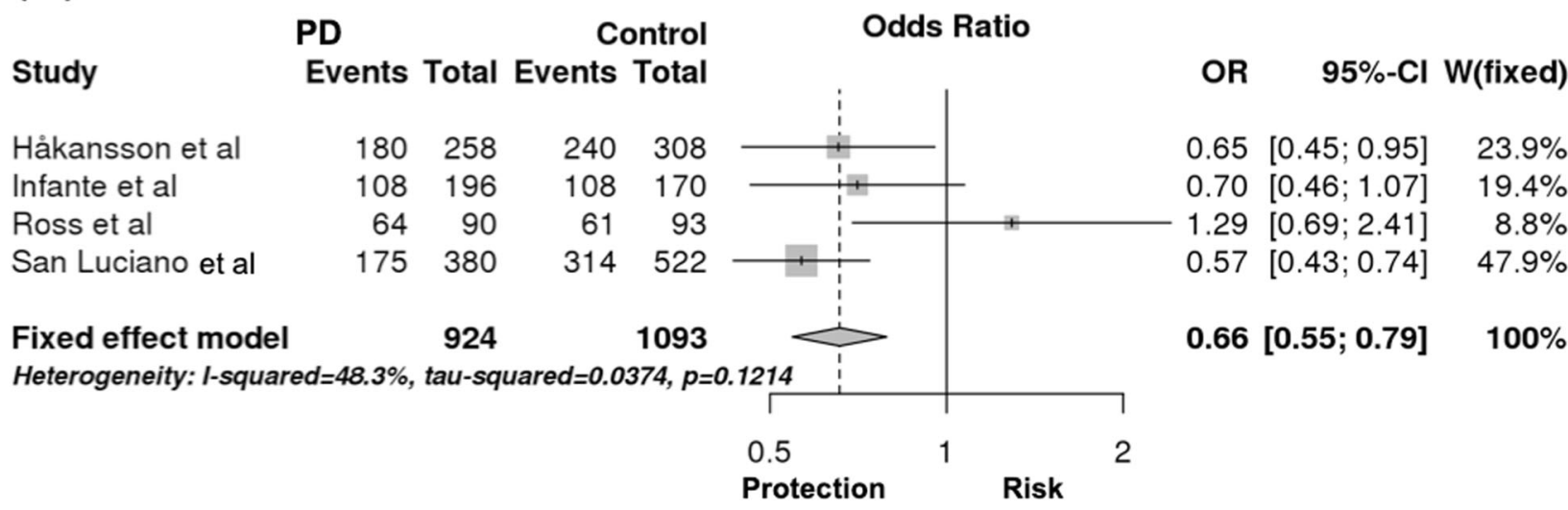

\section{(B) $G C$ vs $G G$}

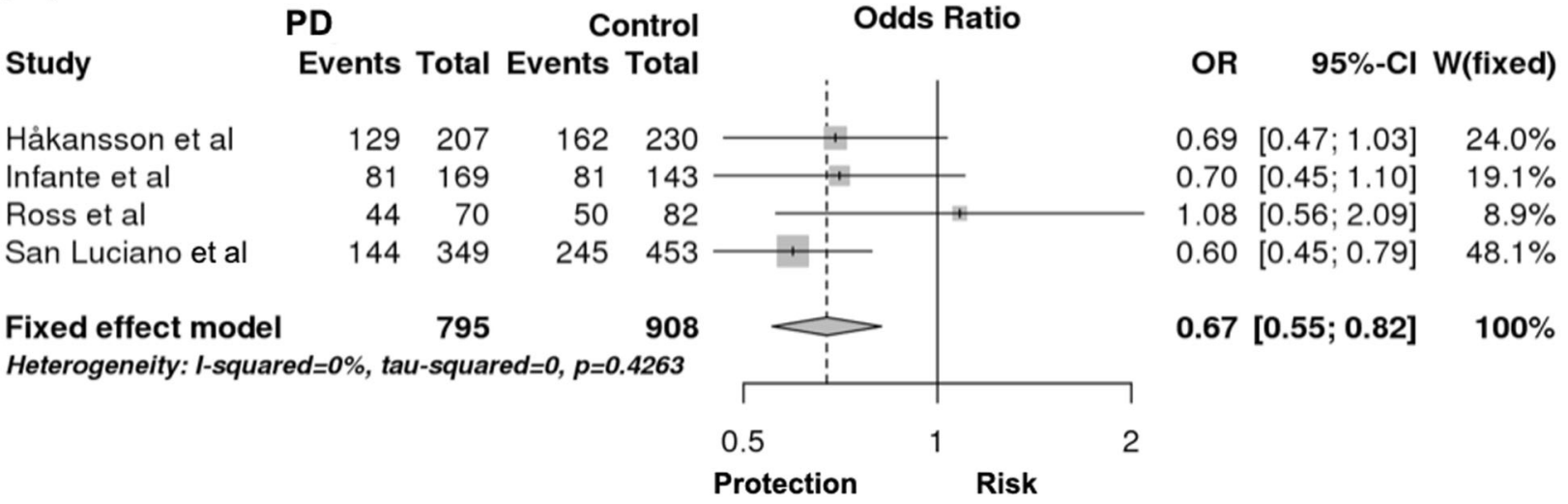

Fig. 3 Association of IL-6 -176 G/C polymorphism with PD. a The dominant model. b The heterozygous model 


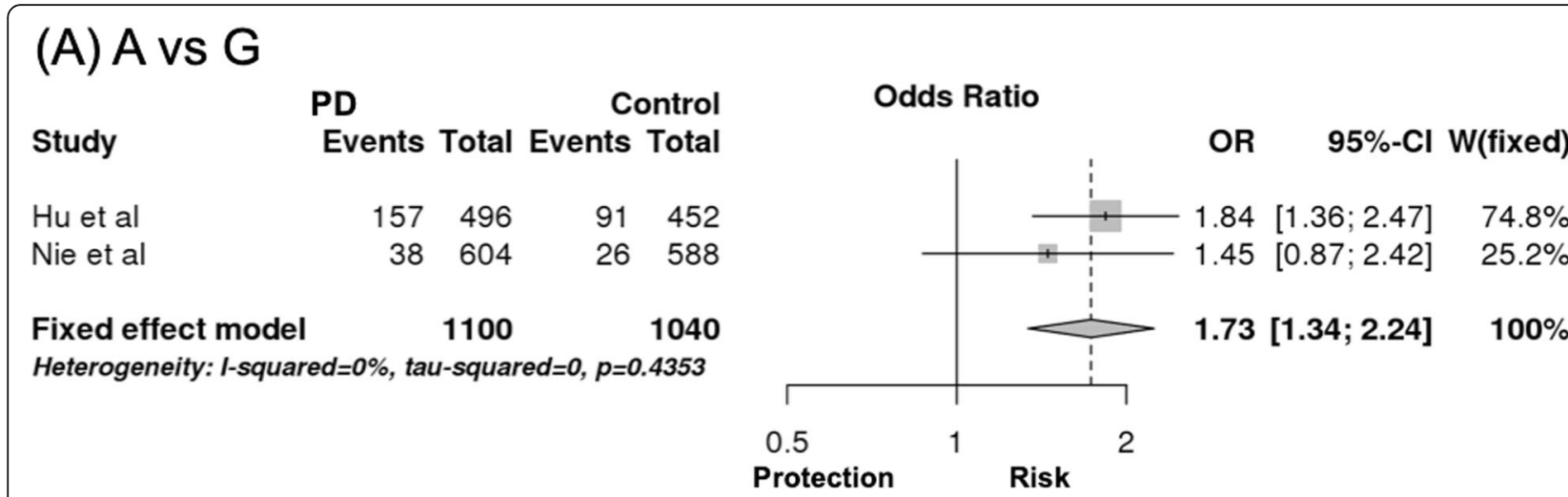

\section{(B) $A A+G A$ vs $G G$}

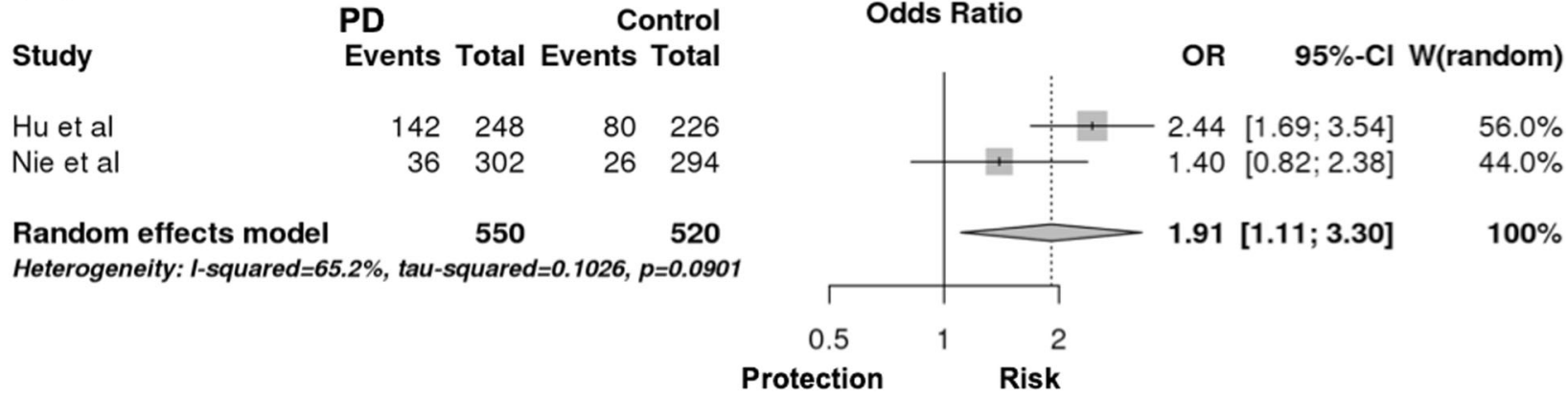

\section{(C) C vs T}

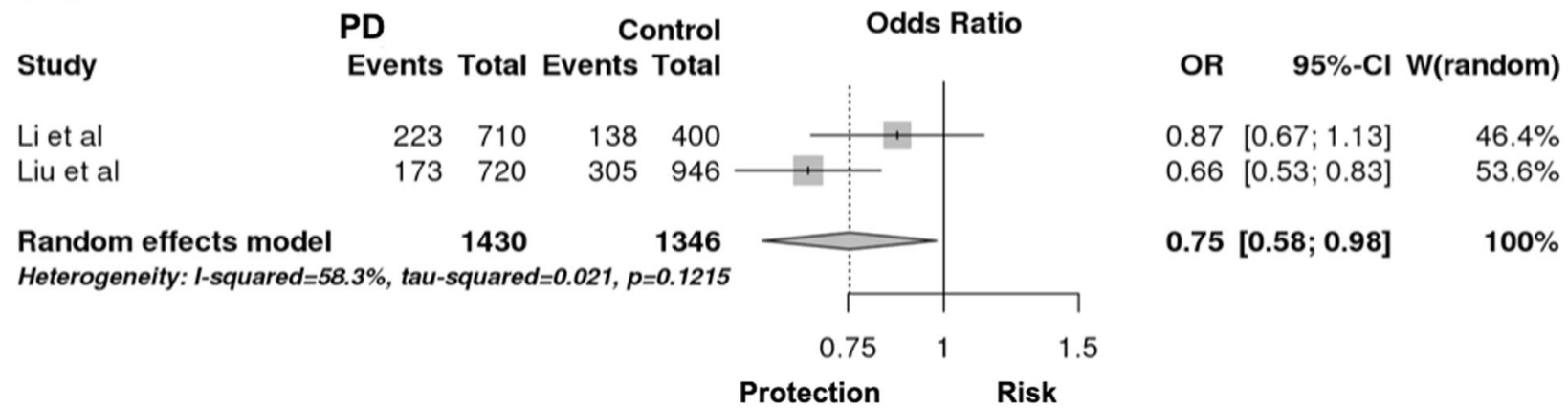

Fig. 4 Association of IL-10 -1082 G/A and IL-10 -819 T/C polymorphisms with PD. a The allelic model in IL-10 -1082 G/A. b The dominant model in IL-10 -1082 G/A. c The allelic model in IL-10 -819 T/C

this study did not change the results (data not shown). No associations with PD were found for all TNF $\alpha$ polymorphism types (Supplemental Table 2).

In addition to the aforementioned genes, polymorphisms for IL-8 -251 A/T (rs4073) [13, 14, 20], IL-18 -607 C/A (rs1946518) [3, 39], IL-18 -137 G/C (rs187238) $[3,35]$, IFNY +874 T/A (rs2430561) [17, 36], MCP1/ CCL2 + 2518A/G (rs1064211) [19-21, 40, 41], and CCR2 + 190 G/A (V64I; rs1799864) [19, 20, 40, 41] were also evaluated. No associations were detected between IL-18 -137 G/C, IFNY+874T/A, and MCP1/CCL2 $+2518 \mathrm{~A} / \mathrm{G}$ and PD risk (Supplemental Table 2).
Meanwhile, the IL-8 -251 A/T polymorphism showed that the allelic ( $\mathrm{T}$ vs. A, OR $=0.812$; 95\% CI $0.665-$ $0.992, P=0.041, I^{2}=0 \%$, Fig. $5 \mathrm{a}$ ) and recessive (TT vs. $\mathrm{AT}+\mathrm{AA}, \mathrm{OR}=0.663 ; 95 \%$ CI $0.481-0.914, P=0.012$, $I^{2}=4.62 \%$, Fig. $5 \mathrm{~b}$ ) models had lower PD risks, especially in Caucasian populations (TT vs. $\mathrm{AT}+\mathrm{AA}, \mathrm{OR}=0.639$; 95\% CI 0.454-0.900, $P=0.010, I^{2}=42.50 \%$, Fig. 5c). Significant associations with PD were also observed for IL$18-607 \mathrm{C} / \mathrm{A}$ and CCR2 +190 G/A. The dominant and heterozygous models of the IL-18 -607 C/A polymorphism were significantly reduced for PD risk $(\mathrm{OR}=0.597$; 95\% CI 0.394-0.905, $P=0.015, I^{2}=0 \%$ and $\mathrm{OR}=0.534$; 


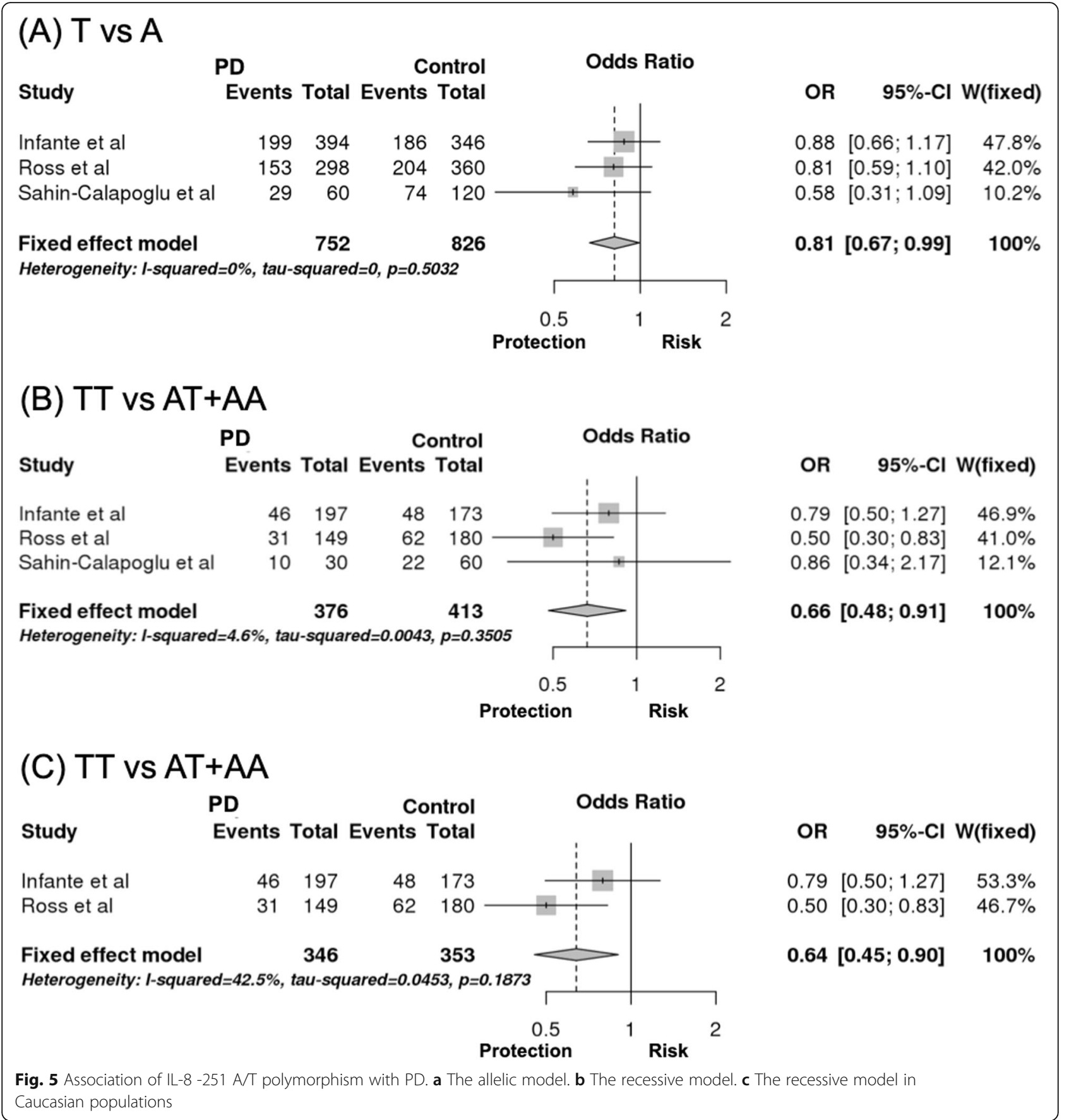

95\% CI $0.344-0.830, P=0.005, I^{2}=0 \%$ ), respectively (Fig. 6a, b). In parallel, recessive and homozygous models of CCR2 +190 G/A also decreased the risk of developing $\mathrm{PD}(\mathrm{OR}=0.552$; 95\% CI 0.338-0.903, $P=$ $0.018, I^{2}=0 \%$ and OR $=0.554 ; 95 \%$ CI $0.336-0.914, P=$ $0.005, \mathrm{I}^{2}=0 \%$ ), respectively (Fig. 7a, b). For CCR2 analyses, studies deviating from HWE [3, 19, 39] (Supplemental Table 1) were not excluded from the evaluation, because of the highly limited study numbers. Begg's funnel plot (data not shown) and the Egger's test were applied, but no publication bias was identified $\left(P_{\text {Egger's test }}>0.05\right)$ (Supplemental Table 2).

\section{Discussion}

In this meta-analysis, a comprehensive investigation of associations between inflammation-related gene polymorphisms and PD risk was performed. Our findings suggest a negative association between IL- $1 \alpha-889 \mathrm{C} / \mathrm{T}$ and PD in Asian populations; the T allele, as well as the TT and CT genotype conveyed a lower risk for PD, which differed 


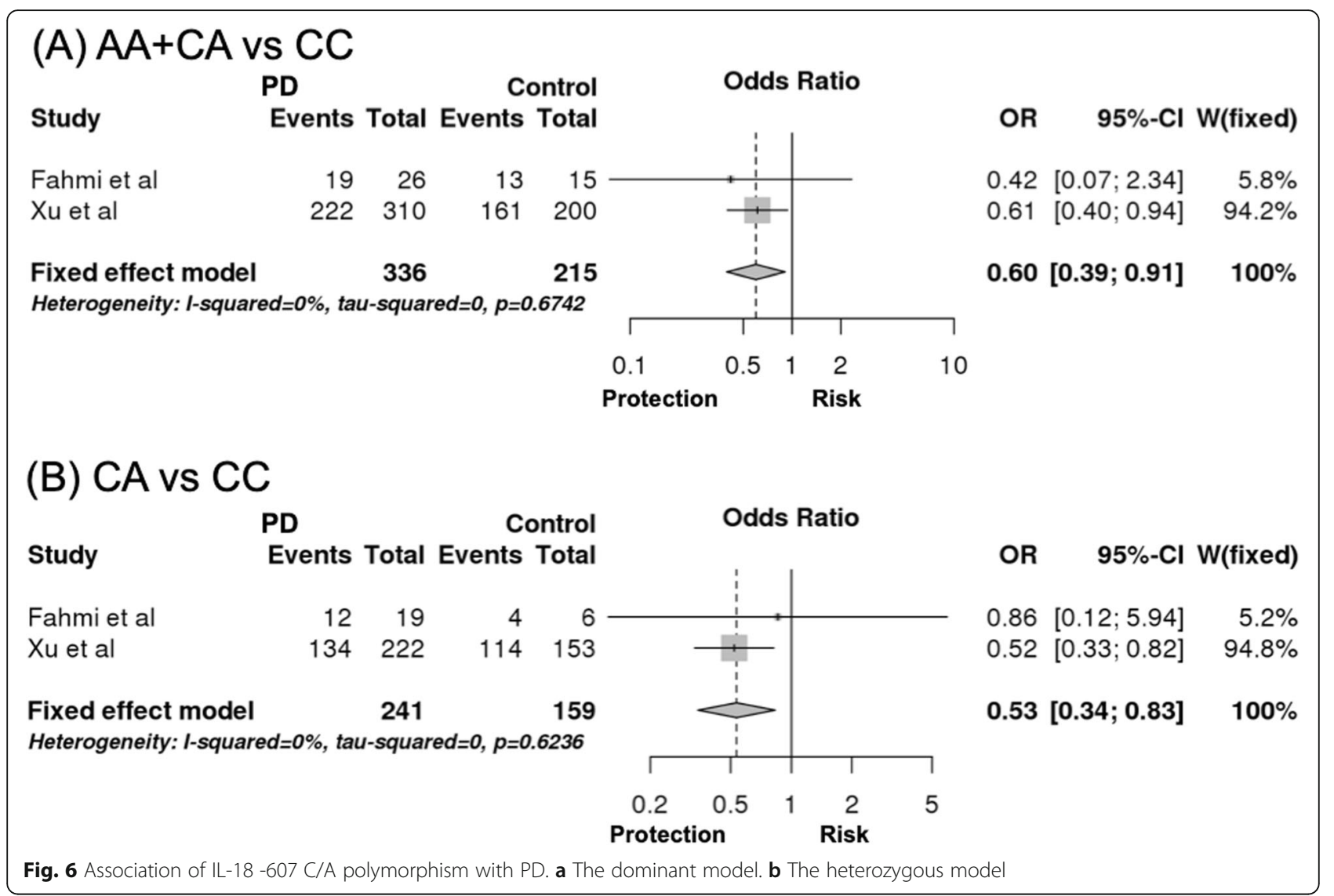

with previous reports [1, 22]. Furthermore, a previous study also demonstrated that the T allele of IL- $1 \alpha(+889$ $\mathrm{C} / \mathrm{T}$ ) was associated with better cognitive function in the elderly [42]. Interestingly, a previous study also reported that the TT genotype of IL- $1 \alpha(+889 \mathrm{C} / \mathrm{T})$ had significantly increased promoter activity, and that its mRNA levels compared well with the CC genotype [43]. Thus, further studies evaluating IL- $1 \alpha$ levels and the TT genotype are required to investigate relationships between these molecular phenomenon and PD risk.

This study also reinforces a previous finding that carriers of the $C$ allele in IL-6 -176 G/C showed a lower risk for $\mathrm{PD}$, particularly in Caucasian populations $[13,14,17]$. A strong association was also observed in this study between PD and IL-10-1082 G/A, in which risk increased for Asian individuals carrying the $\mathrm{A}$ allele and decreased in the $\mathrm{C}$ allele. These findings contrast with the pooled results from previously reported studies that show lack of association between the IL-101082 G/A with PD risk. Production of the antiinflammatory cytokine IL-10 is crucial to prevent damage driven by excessive inflammation [44]. This neuroprotective role of IL-10 has been extensively studied in PD, an example of which is a study showing that administration of a recombinant human IL-10 in the PD model improves forelimb akinesia [45]. However, definitive IL-10 levels in PD are equivocal [46-48]. Larsson et al. demonstrated that IL-10 mRNA expression was higher in the GG, rather than the AA genotype [49], suggesting that A allele carriers with the IL-10 -1082 G/A genotype, may express low IL-10 levels. In contrast, the C allele of the IL-10 -819 T/C genotype tends to generate higher IL-10 mRNA expression levels [50]. Together, these results support the oppositional effect of IL-10 -1082 G/A and IL-10 -819 T/C polymorphisms on the expression levels of IL-10, which was also observed in this current study. Nevertheless, studies with larger sample sizes are required to validate the effects of IL-10 -1082 G/A and IL-10 -819 T/C polymorphisms on PD progression.

The pooled results indicated a decreased risk for PD in IL-18 -607A carriers. IL-18 exerts pleiotropic affects and is believed to mediate neuroinflammation and neurodegeneration [3, 39]. And although it is known that IL-18 expression is regulated by polymorphism of IL-18607C/A [39], to date no reports exist regarding the level of IL-18 in serum or CSF of PD subjects.

Lastly, we also showed a protective role for $\mathrm{T}$ and $\mathrm{A}$ alleles in the chemokines, IL-8 $-251 \mathrm{~A} / \mathrm{T}$ and CCR2 +190 G/A polymorphisms, respectively. Elevated IL-8 mRNA expression and IL-8 serum levels were correlated 


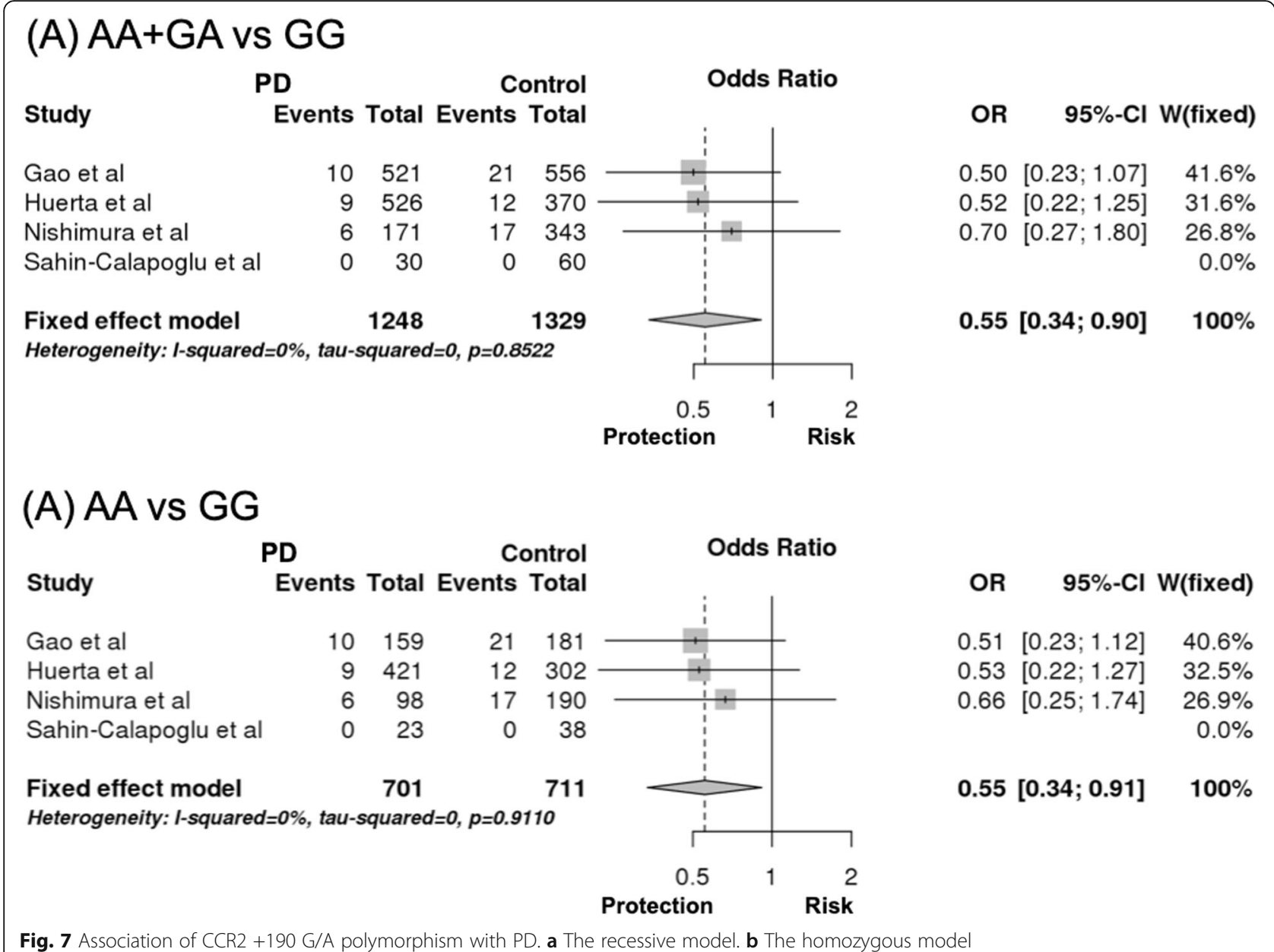

with an IL-8 -251A carrier [51], while the AA genotype of CCR2 +190 G/A was reported to exert protective effects against Alzheimer's disease (AD) progression [52], though another study in the same population showed insignificant results [53]. Together, these results suggest that chemokine/chemokine receptor interactions are essential in directing inflammatory response in injured or degenerated neuronal tissues.

\section{Conclusions}

Despite the strengths of this study, there were some limitations, such as the limited number of studies available. Thus, gene effect estimates on PD may not be precise. Notwithstanding this issue, PD etiology is multifactorial; therefore, the interplay of genetic, hormonal, and environmental factors must be investigated and verified in larger cohort studies.

In conclusion, we observed that IL-1 $\alpha-889$, IL-6 -176, IL-8 -251, IL-10 -1082, IL-10 -819, IL-18 -607, and CCR2 +190 polymorphisms were associated with PD susceptibility; however, more studies will be required to definitively verify these conclusions.

\section{Supplementary information}

Supplementary information accompanies this paper at https://doi.org/10. 1186/s43042-020-00056-6.

Additional file 1: Supplemental Table 1. Characteristic of individual studies for the association between inflammation-related gene polymorphisms and PD. Supplemental Table 2. Meta-analysis for the association between between inflammation-related gene polymorphisms and PD.

\section{Abbreviations}

A: Adenine; AD: Alzheimer disease; C: Cytosine; CCL2: C-C Motif Chemokine Ligand 2; CCR2: C-C chemokine receptor type 2; CCR5: C-C chemokine receptor type 5; Cl: Confidence interval; CNS: Central nervous system; CSF: Cerebrospinal fluid; CXCL8: C-X-C Motif Chemokine Ligand 8; DA: Dopaminergic; FEM: Fixed-effect model; G: Guanine; HWE: HardyWeinberg equilibrium; IFNY: Interferon gamma; IL-1a: Interleukin-1 alpha; IL13: Interleukin-1 beta; IL-2: Interleukin-2; IL-3: Interleukin-3; IL-6: Interleukin-6; IL-8: Interleukin-8; IL-10: Interleukin-10; IL-18: Interleukin-18; M: Mutant type; MCP1: Monocyte chemoattractant protein 1; mRNA: Messenger ribonucleic acid; OR: Odds ratio; PD: Parkinson's disease; REM: Random-effect model;

T: Thymine; TH: Tyrosine hydroxylase; TNFa: Tumor necrosis factor alpha; W: Wild type

\section{Acknowledgements}

The authors would like to thank to Gita Vita Soraya for her thoughtful comments and efforts towards improving our manuscript. 


\section{Authors' contributions}

ZU designed, performed, analyzed, and wrote the manuscript. CG analyzed and wrote the manuscript. All authors have read and approved the final manuscript.

\section{Authors' information}

Zulvikar Syambani Ulhaq is a lecturer at the Department of Biomedical Science, Faculty of Medicine and Health Sciences, Maulana Malik Ibrahim Islamic State University of Malang, Indonesia. His current interests are neuroestrogen and neuro-ophthalmology. Email: zulhaq@kedokteran.uin-malang.ac.id.

Cristian Peinado Garcia is a medical doctor working at Department of General Surgery, Weston General Hospital, Grange Rd, Weston-super-Mare, BS23 4QT, UK. Email: Cristian.Peinado@nhs.net.

\section{Funding}

The author received no specific funding for this work.

\section{Availability of data and materials}

All data and supplementary materials are available in the manuscript.

\section{Ethics approval and consent to participate}

Not applicable

\section{Consent for publication}

Not applicable

\section{Competing interests}

The authors declare that they have no competing interests.

\section{Author details}

'Department of Biomedical Science, Faculty of Medicine and Health Sciences, Maulana Malik Ibrahim Islamic State University of Malang, Batu, East Java 65151, Indonesia. ${ }^{2}$ Department of General Surgery, Weston General Hospital, Grange Rd, Weston-super-Mare BS23 4QT, UK.

Received: 1 November 2019 Accepted: 9 March 2020 Published online: 06 April 2020

\section{References}

1. Liu GJ, Feng RN, Luo C, Bi S (2010) Lack of association between interleukin1 alpha, beta polymorphisms and Parkinson's disease. Neurosci Lett. 480(2): 158-161. https://doi.org/10.1016/j.neulet.2010.06.032

2. Pascale E, Passarelli E, Purcaro C, Vestri AR, Fakeri A, Guglielmi R et al (2011) Lack of association between IL-1 $\beta$, TNF- $a$, and IL-10 gene polymorphisms and sporadic Parkinson's disease in an Italian cohort. Acta Neurol Scand. 124(3):176-181. https://doi.org/10.1111/j.1600-0404.2010.01441.x

3. Xu X, Li D, He Q, Gao J, Chen B, Xie A (2011) Interleukin-18 promoter polymorphisms and risk of Parkinson's disease in a Han Chinese population. Brain Res. 1381:90-94. https://doi.org/10.1016/j.brainres.2011.01.025

4. Li D, He Q, Li R, Xu X, Chen B, Xie A (2012) Interleukin-10 promoter polymorphisms in Chinese patients with Parkinson's disease. Neurosci Lett. 513(2):183-186. https://doi.org/10.1016/j.neulet.2012.02.033

5. Ryczko D, Dubuc R (2017) Dopamine and the brainstem locomotor networks: from lamprey to human. Front Neurosci. 11:295. https://doi.org/ 10.3389/fnins.2017.00295

6. Zhou YT, Yang JF, Zhang YL, Wang XY, Chan P (2008) Protective role of interlekin-1 alpha gene polymorphism in Chinese Han population with sporadic Parkinson's disease. Neurosci Lett. 445(1):23-25. https://doi.org/10. 1016/j.neulet.2008.08.054

7. San Luciano M, Ozelius L, Lipton RB, Raymond D, Bressman SB, SaundersPullman R (2012) Gender differences in the IL6 -174G > C and ESR2 $1730 G$ $>$ A polymorphisms and the risk of Parkinson's disease. Neurosci Lett. 506(2):312-316. https://doi.org/10.1016/j.neulet.2011.11.032

8. Wu YR, Chen CM, Hwang JC, Chen ST, Feng IH, Hsu HC et al (2007) Interleukin-1 alpha polymorphism has influence on late-onset sporadic Parkinson's disease in Taiwan. J Neural Transm (Vienna). 114(9):1173-1177. https://doi.org/10.1007/s00702-007-0726-4

9. Krüger R, Hardt C, Tschentscher F, Jäckel S, Kuhn W, Müller T et al (2000) Genetic analysis of immunomodulating factors in sporadic Parkinson's disease. J Neural Transm (Vienna). 107(5):553-562. https://doi.org/10.1007/ s007020070078

10. Håkansson A, Westberg L, Nilsson S, Buervenich S, Carmine A, Holmberg B et al (2005) Interaction of polymorphisms in the genes encoding interleukin-6 and estrogen receptor beta on the susceptibility to Parkinson's disease. Am J Med Genet B Neuropsychiatr Genet. 133B(1):88-92. https:// doi.org/10.1002/ajmg.b.30136

11. Wahner AD, Sinsheimer JS, Bronstein JM, Ritz B (2007) Inflammatory cytokine gene polymorphisms and increased risk of Parkinson's disease. Arch Neurol. 64(6):836-840. https://doi.org/10.1001/archneur.64.6.836

12. Bialecka M, Klodowska-Duda G, Kurzawski M, Slawek J, Opala G, Bialecki $P$ et al (2007) Interleukin-10 gene polymorphism in Parkinson's disease patients. Arch Med Res. 38(8):858-863. https://doi.org/10.1016/j.arcmed. 2007.06.006

13. Infante J, García-Gorostiaga I, Sánchez-Juan P, Sánchez-Quintana C, Gurpegui JL, Rodríguez-Rodríguez E et al (2008) Inflammation-related genes and the risk of Parkinson's disease: a multilocus approach. Eur J Neurol. 15(4):431-433. https://doi.org/10.1111/j.1468-1331.2008.02092.x

14. Ross OA, O'Neill C, Rea IM, Lynch T, Gosal D, Wallace A et al (2004) Functional promoter region polymorphism of the proinflammatory chemokine IL-8 gene associates with Parkinson's disease in the Irish. Hum Immunol. 65(4):340-346. https://doi.org/10.1016/j.humimm.2004.01.015

15. McGeer PL, Yasojima K, McGeer EG (2002) Association of interleukin-1 beta polymorphisms with idiopathic Parkinson's disease. Neurosci Lett. 326(1):6769. https://doi.org/10.1016/s0304-3940(02)00300-2

16. Agliardi C, Guerini FR, Zanzottera M, Riboldazzi G, Zangaglia R, Bono G et al (2018) TNF-a -308 G/A and -238 G/A promoter polymorphisms and sporadic Parkinson's disease in an Italian cohort. J Neurol Sci. 385:45-48. https://doi. org/10.1016/j.jns.2017.12.011

17. Håkansson A, Westberg L, Nilsson S, Buervenich S, Carmine A, Holmberg B et al (2005) Investigation of genes coding for inflammatory components in Parkinson's disease. Mov Disord. 20(5):569-573. https://doi.org/10.1002/mds.20378

18. Papageorgiou IE, Lewen A, Galow LV, Cesetti T, Scheffel J, Regen T et al (2016) TLR4-activated microglia require IFN- $\gamma$ to induce severe neuronal dysfunction and death in situ. Proc Natl Acad Sci USA. 113(1):212-217. https://doi.org/10.1073/pnas.1513853113

19. Huerta C, Alvarez V, Mata IF, Coto E, Ribacoba R, Martínez C et al (2004) Chemokines (RANTES and MCP-1) and chemokine-receptors (CCR2 and CCR5) gene polymorphisms in Alzheimer's and Parkinson's disease. Neurosci Lett. 370(2-3):151-154. https://doi.org/10.1016/j.neulet.2004.08.016

20. Sahin-Calapoglu N, Demirci S, Calapoglu M, Yasar B (2016) A case-control association study of RANTES $(-28 C>$ G) polymorphism as a risk factor for Parkinson's disease in Isparta, Turkey. Parkinson's Dis. 2016:5042604. https://doi.org/10.1155/2016/5042604

21. Shen R, Lin S, He L, Zhu X, Zhou Z, Chen S et al (2019) Association of two polymorphisms in CCL2 with Parkinson's disease: a case-control study. Front Neurol. 10:35. https://doi.org/10.3389/fneur.2019.00035

22. Chu K, Zhou X, Luo BY (2012) Cytokine gene polymorphisms and Parkinson's disease: a meta-analysis. Can J Neurol Sci. 39(1):58-64. https://doi.org/10.1017/s0317167100012695

23. Dai $D$, Lin $P$, Wang $Y$, Zhou $X$, Tao J, Jiang $D$ et al (2014) Association of NQO1 and TNF polymorphisms with Parkinson's disease: a meta-analysis of 15 genetic association studies. Biomed Rep. 2(5):713-718. https://doi.org/10. 3892/br.2014.296

24. Zhang J, Zhao T, Xu C, Yu H (2018) Four polymorphisms in the IL-22 gene and the risk of cancer: a meta-analysis. J Evid Based Med. 11(2):101-104. https://doi.org/10.1111/jebm.12296

25. Boonpheng B, Thongprayoon C, Cheungpasitporn W (2018) The comparison of risk of stroke in patients with peritoneal dialysis and hemodialysis: a systematic review and meta-analysis. J Evid Based Med. 11(3):158-168. https://doi.org/10.1111/jebm.12315

26. Arman A, Isik N, Coker A, Candan F, Serap Becit K, List EO (2010) Association between sporadic Parkinson's disease and interleukin-1 beta -511 gene polymorphisms in the Turkish population. Eur Cytokine Netw. 21(2):116-121. https://doi.org/10.1684/ecn.2010.0186

27. Dodel RC, Lohmüller F, Du Y, Eastwood B, Gocke P, Oertel WH et al (2001) A polymorphism in the intronic region of the IL-1alpha gene and the risk for Parkinson's disease. Neurology. 56(7):982-983. https://doi.org/10.1212/wnl. 56.7 .982

28. Mattila KM, Rinne JO, Lehtimäki T, Röyttä M, Ahonen JP, Hurme M (2002) Association of an interleukin 1B gene polymorphism (-511) with Parkinson's 
disease in Finnish patients. J Med Genet. 39(6):400-402. https://doi.org/10. 1136/jmg.39.6.400

29. Möller JC, Depboylu C, Kölsch H, Lohmüller F, Bandmann O, Gocke P et al (2004) Lack of association between the interleukin-1 alpha (-889) polymorphism and early-onset Parkinson's disease. Neurosci Lett. 359(3): 195-197. https://doi.org/10.1016/j.neulet.2004.01.058

30. Nishimura M, Mizuta I, Mizuta E, Yamasaki S, Ohta M, Kuno S (2000) Influence of interleukin-1beta gene polymorphisms on age-at-onset of sporadic Parkinson's disease. Neurosci Lett. 284(1-2):73-76. https://doi.org/ 10.1016/s0304-3940(00)00991-5

31. Schulte T, Schöls L, Müller T, Woitalla D, Berger K, Krüger R (2002) Polymorphisms in the interleukin-1 alpha and beta genes and the risk for Parkinson's disease. Neurosci Lett. 326(1):70-72. https://doi.org/10.1016/ s0304-3940(02)00301-4

32. Nishimura M, Kuno S, Kaji R, Yasuno K, Kawakami H (2005) Glutathione-Stransferase-1 and interleukin-1 beta gene polymorphisms in Japanese patients with Parkinson's disease. Mov Disord. 20(7):901-902. https://doi.org/ $10.1002 /$ mds. 20477

33. Hu W, Chen Y, Zhao H (2017) Association of pro-inflammatory cytokine gene polymorphisms with Parkinson's disease in Chinese population. Int J Clin Exp Med. 10(2):3661-3668

34. Bialecka M, Klodowska-Duda G, Kurzawski M, Slawek J, Gorzkowska A, Opala G et al (2008) Interleukin-10 (IL10) and tumor necrosis factor alpha (TNF) gene polymorphisms in Parkinson's disease patients. Parkinsonism Relat Disord. 14(8):636-640. https://doi.org/10.1016/j.parkreldis.2008.02.001

35. Liu Z, Guo J, Wang Y, Li K, Kang J, Wei Y et al (2016) Lack of association between IL-10 and IL-18 gene promoter polymorphisms and Parkinson's disease with cognitive impairment in a Chinese population. Sci Rep. 6 : 19021. https://doi.org/10.1038/srep19021

36. Nie K, Zhang Y, Gan R, Wang L, Zhao J, Huang Z et al (2013) Polymorphisms in immune/inflammatory cytokine genes are related to Parkinson's disease with cognitive impairment in the Han Chinese population. Neurosci Lett. 541:111-115. https://doi.org/10.1016/j.neulet.2013.02.024

37. Redenšek S, Flisar D, Kojović $M$, Kramberger MG, Georgiev D, Pirtošek Z et al (2019) Genetic variability of inflammation and oxidative stress genes does not play a major role in the occurrence of adverse events of dopaminergic treatment in Parkinson's disease. J Neuroinflammation. 16(1):50. https://doi. org/10.1186/s12974-019-1439-y

38. Nishimura M, Mizuta I, Mizuta E, Yamasaki S, Ohta M, Kaji R et al (2001) Tumor necrosis factor gene polymorphisms in patients with sporadic Parkinson's disease. Neurosci Lett. 311(1):1-4. https://doi.org/10.1016/s03043940(01)02111-5

39. Fahmy E, Rabah A, Sharaf S, Helmy H, Kamal A (2019) Interleukin-18 promoter polymorphisms and idiopathic Parkinson's disease: an Egyptian study. Acta Neurol Belg. 119(2):219-224. https://doi.org/10.1007/s13760-018-0927-7

40. Nishimura M, Kuno S, Mizuta I, Ohta M, Maruyama H, Kaji R et al (2003) Influence of monocyte chemoattractant protein 1 gene polymorphism on age at onset of sporadic Parkinson's disease. Mov Disord. 18(8):953-955. https://doi.org/10.1002/mds.10462

41. Gao L, Tang H, Nie K, Wang L, Zhao J, Gan R et al (2015) MCP-1 and CCR2 gene polymorphisms in Parkinson's disease in a Han Chinese cohort. Neurol Sci. 36(4):571-576. https://doi.org/10.1007/s10072-014-1990-3

42. Wang EH, Hong CJ, Yeh HL, Liou YJ, Yang AC, Liu ME et al (2013) Interleukin-1 alpha (rs1800587) genetic polymorphism is associated with specific cognitive functions but not depression or loneliness in elderly males without dementia. Neurosci Lett. 556:69-72. https://doi.org/10.1016/j. neulet.2013.09.057

43. Dominici R, Cattaneo M, Malferrari G, Archi D, Mariani C, Grimaldi LM et al (2002) Cloning and functional analysis of the allelic polymorphism in the transcription regulatory region of interleukin-1 alpha. Immunogenetics. 54(2):82-86. https://doi.org/10.1007/s00251-002-0445-9

44. Lobo-Silva D, Carriche GM, Castro AG, Roque S, Saraiva M (2016) Balancing the immune response in the brain: $\| \mathrm{L}-10$ and its regulation. J Neuroinflammation. 13(1):297. https://doi.org/10.1186/s12974-016-0763-8

45. Johnston LC, Su X, Maguire-Zeiss K, Horovitz K, Ankoudinova I, Guschin D et al (2008) Human interleukin-10 gene transfer is protective in a rat model of Parkinson's disease. Mol Ther. 16(8):1392-1399. https://doi.org/10.1038/ mt.2008.113

46. Schröder JB, Pawlowski M, Meyer Zu Hörste G, Gross CC, Wiendl H, Meuth SG et al (2018) Immune cell activation in the cerebrospinal fluid of patients with Parkinson's disease. Front Neurol. 9:1081. https://doi.org/10.3389/fneur. 2018.01081

47. Starhof C, Winge K, Heegaard NHH, Skogstrand K, Friis S, Hejl A (2018) Cerebrospinal fluid pro-inflammatory cytokines differentiate parkinsonian syndromes. J Neuroinflammation. 15(1):305. https://doi.org/10.1186/s12974018-1339-6

48. Rathnayake D, Chang T, Udagama P (2019) Selected serum cytokines and nitric oxide as potential multi-marker biosignature panels for Parkinson's disease of varying durations: a case-control study. BMC Neurol. 19(1):56. https://doi.org/10.1186/s12883-019-1286-6

49. Larsson L, Rymo L, Berglundh T (2010) Sp1 binds to the $\mathrm{G}$ allele of the-1087 polymorphism in the IL-10 promoter and promotes IL-10 mRNA transcription and protein production. Genes Immun. 11(2):181-187. https:// doi.org/10.1038/gene.2009.103

50. Hu J, Hou S, Zhu X, Fang J, Zhou Y, Liu Y et al (2015) Interleukin-10 gene polymorphisms are associated with Behcet's disease but not with Vogt-KoyanagiHarada syndrome in the Chinese Han population. Mol Vis. 21:589-603

51. Gonzalez-Hormazabal P, Romero S, Musleh M, Bustamante M, Stambuk J, Pisano R et al (2018) IL-8-251 T>A (rs4073) polymorphism is associated with prognosis in gastric cancer patients. Anticancer Res 38(10):5703-5708. https://doi.org/10.21873/anticanres.12907

52. Gharesouran J, Rezazadeh M, Mojtaba S, Ardebili M (2013) Investigation of five polymorphic DNA markers associated with late onset Alzheimer's disease. Genetika. 45(2):503-514. https://doi.org/10.2298/GENSR1302503G

53. Khorram Khorshid HR, Manoochehri M, Nasehi L, Ohadi M, Rahgozar M, Kamali K (2012) Ccr2-64i and Ccr5 $\Delta 32$ polymorphisms in patients with lateonset Alzheimer's disease; a study from Iran (Ccr2-64i And Ccr5 $\Delta 32$ polymorphisms in Alzheimer's disease). Iran J Basic Med Sci. 15(4):937-944

\section{Publisher's Note}

Springer Nature remains neutral with regard to jurisdictional claims in published maps and institutional affiliations.

\section{Submit your manuscript to a SpringerOpen ${ }^{\circ}$ journal and benefit from:}

- Convenient online submission

- Rigorous peer review

- Open access: articles freely available online

High visibility within the field

- Retaining the copyright to your article

Submit your next manuscript at $>$ springeropen.com 